\title{
Ammonia production from amino acid-based biomass-like sources by engineered Escherichia coli
}

Yosuke Mikami $^{1 \dagger}$, Hisanari Yoneda ${ }^{1 \dagger}$, Yohei Tatsukami ${ }^{1,2}$, Wataru Aoki ${ }^{1,3}$ and Mitsuyoshi Ueda ${ }^{1,3^{*}}$

\begin{abstract}
The demand for ammonia is expected to increase in the future because of its importance in agriculture, industry, and hydrogen transportation. Although the Haber-Bosch process is known as an effective way to produce ammonia, the process is energy-intensive. Thus, an environmentally friendly ammonia production process is desired. In this study, we aimed to produce ammonia from amino acids and amino acid-based biomass-like resources by modifying the metabolism of Escherichia coli. By engineering metabolic flux to promote ammonia production using the overexpression of the ketoisovalerate decarboxylase gene (kivd), derived from Lactococcus lactis, ammonia production from amino acids was $351 \mathrm{mg} / \mathrm{L}$ (36.6\% yield). Furthermore, we deleted the $\mathrm{g} / \mathrm{n} A$ gene, responsible for ammonia assimilation. Using yeast extract as the sole source of carbon and nitrogen, the resultant strain produced $458 \mathrm{mg} / \mathrm{L}$ of ammonia (47.8\% yield) from an amino acid-based biomass-like material. The ammonia production yields obtained are the highest reported to date. This study suggests that it will be possible to produce ammonia from waste biomass in an environmentally friendly process.
\end{abstract}

Keywords: Ammonia, Metabolic engineering, Escherichia coli, Biorefinery

\section{Introduction}

Ammonia is one of the most valuable materials in all aspects of our daily life. Mostly, it is used as a fertilizer in agriculture, and another important usage is as a precursor for nitrogen-containing chemicals such as nitriles, amines, hydrazine, and urea. Additionally, it is anticipated that ammonia has potentiality as a hydrogen liquid carrier in the proposed hydrogen economy (Lan et al. 2012; Miura and Tezuka 2014).

Ammonia synthesis was industrially started by Haber at the beginning of the twentieth century. The Haber-Bosch process now sustains our life by supplying nitrogen fertilizers, keeping up with the increasing demands for food (Erisman et al. 2008). Global production of ammonia reached 146 million tons in 2015 (Gocha 2015). However, we have to consider energy consumption of ammonia

\footnotetext{
*Correspondence: miueda@kais.kyoto-u.ac.jp

${ }^{\dagger}$ Yosuke Mikami and Hisanari Yoneda contributed equally to this work

1 Division of Applied Life Sciences, Graduate School of Agriculture, Kyoto

University, Sakyo-ku, Kyoto 606-8502, Japan

Full list of author information is available at the end of the article
}

production by the Haber-Bosch process because the process needs a lot of energy. The process requires high temperatures $\left(400-600{ }^{\circ} \mathrm{C}\right)$ and high pressures $(20-$ $40 \mathrm{MPa}$ ), and it is said that more than $1 \%$ of the energy generated in the world is used for the Haber-Bosch process (Schrock 2006). Therefore, a more environmentally friendly ammonia production process is desired.

Ammonia production using microorganisms from waste biomass, which is abundant and nitrogen-rich, can be performed at ordinary temperatures and normal pressures. Cleavage of the nitrogen-nitrogen triple bond consumes maximum energy in the Haber-Bosch process. In contrast, nitrogen is already fixed in waste biomass, so ammonia can be easily produced by bacterial dissimilation.

In this study, we show a general concept of ammonia production from waste biomass with metabolically engineered microorganisms. To efficiently produce ammonia, Escherichia coli (E. coli) was chosen as the host strain because of the accumulated knowledge of its metabolism (Deng et al. 2005; Yim et al. 2011). We planned to direct 
the amino acid degradation pathway to produce ammonia. First, overexpression of a decarboxylase gene was used as a driving force for ammonia production. Second, we prepared E. coli strains that lacked the genes involved in ammonia assimilation, and investigated their influence on ammonia production. By combining these two strategies, we constructed an E. coli strain suitable for ammonia production.

\section{Materials and methods \\ Media}

Luria-Bertani (LB) medium was prepared with $10 \mathrm{~g} / \mathrm{L}$ Bacto $^{\text {TM }}$ Tryptone (Becton, Dickinson and Company, Detroit, MI, USA), $5 \mathrm{~g} / \mathrm{L} \mathrm{Bacto}^{\mathrm{TM}}$ Yeast Extract (Becton) and $10 \mathrm{~g} / \mathrm{L} \mathrm{NaCl}$ (Wako chemicals, Osaka, Japan). M9-YE medium was prepared with $6 \mathrm{~g} / \mathrm{L} \mathrm{K}_{2} \mathrm{HPO}_{4}, 3 \mathrm{~g} / \mathrm{L}$ $\mathrm{KH}_{2} \mathrm{PO}_{4}, 0.5 \mathrm{~g} / \mathrm{L} \mathrm{NaCl}, 7.25 \mathrm{~g} / \mathrm{L}$ yeast extract, $0.1 \mathrm{mM}$ $\mathrm{CaCl}_{2}$, and $1 \mathrm{mM} \mathrm{MgSO}$. In the experiment for the examination of effects of nitrogen sources on ammonia production, Bacto ${ }^{\mathrm{TM}}$ Tryptone (Becton), Bacto ${ }^{\mathrm{TM}}$ Peptone (Becton), or Bacto ${ }^{\mathrm{TM}}$ Casamino acids (Becton) were used instead of Bacto ${ }^{\mathrm{TM}}$ Yeast Extract in M9-YE medium. Ampicillin (Meiji Seika Pharma, Tokyo, Japan, $100 \mu \mathrm{g} /$ $\mathrm{mL}$ ) and kanamycin (Nacalai Tesque, Kyoto, Japan, $25 \mu \mathrm{g} /$ $\mathrm{mL}$ ) were added as appropriate.

\section{Construction of $E$. coli strains}

All primers and strains used in this study are listed in Table 1 and Additional file 1: Table S1, respectively. To clone the kivd gene, which encodes keto acid decarboxylase, genomic DNA of a Lactococcus lactis subsp. (ATCC 19435D-5, purchased from the ATCC), was used as a PCR template, with primers YN31/YN32. To clone cadA, gadA, or $i l v H$ genes, firstly genomic DNA of E.coli
DH5 $\alpha$ (Thermo Fisher Scientific) was extracted using the Genomic-tip 100/G kit (QIAGEN, Hilden, Germany). Next, the genomic DNA was used as a template for PCR amplification with primers YN33/YN34, YN35/YN36, or YN39/YN40, respectively. Resultant PCR products were cloned into the pTrcHis2-TOPO ${ }^{\circledR}$ vector (Thermo Fisher Scientific, Waltham, MA, USA) by TA-cloning (Fig. 1a). The control strain was E. coli DH10B; harboring the plasmid pTrcHis2-TOPO ${ }^{\circledR} /$ lacZ (Thermo Fisher Scientific). Protein production was validated by sodium dodecyl sulfate-polyacrylamide gel electrophoresis (SDS-PAGE) using a 5-20\% e-PAGEL (ATTO, Tokyo, Japan) and Full Range RPN800E protein markers (GE healthcare, Little Chalfont, UK). Proteins on the gel were stained with Coomassie Brilliant Blue (Bio-Rad, Hercules, CA, USA).

Gene deletion was performed using a homologous recombination system using lambda Red proteins according to the method by Datsenko (Fig. 1b) (Datsenko and Wanner 2000). The plasmid and method for gene deletion are shown in Fig. 1a and b, respectively.

\section{Ammonia production}

All cultivations were performed in a shaker (TAITEC, Saitama, Japan) at $165 \mathrm{rpm}$ and $37^{\circ} \mathrm{C}$. For pre-culture, $E$. coli strains were cultivated in $5 \mathrm{~mL} \mathrm{LB}$ medium at $37^{\circ} \mathrm{C}$ overnight. The overnight culture was inoculated into $2.5 \mathrm{~mL}$ of M9-YE medium, or other media, to achieve an initial $\mathrm{OD}_{600}$ value of 0.5 . Cells were grown for $2.5 \mathrm{~h}$ before adding $0.1 \mathrm{mM}$ (final concentration) of isopropyl$\beta$-D-thiogalactoside (IPTG). After adding IPTG, cells were grown for $24 \mathrm{~h}$. Ammonia meter (Ion meter TiN9001, Toko Chemical Laboratories, Tokyo, Japan) was used to measure ammonia dissolved in the culture supernatant. Ammonia yields in M9-YE medium and other

Table 1 Strains and plasmids

\begin{tabular}{|c|c|c|}
\hline Strains or plasmids & Genotype or description & Reference \\
\hline \multicolumn{3}{|l|}{ E. coli strains } \\
\hline $\mathrm{DH} 10 \mathrm{~B}$ & $\begin{array}{l}\text { F-mcrA } \triangle(\text { mrr-hsdRMS-mcrBC) } \Phi 80 \text { lacZ } \triangle \mathrm{M} 15 \Delta \text { lacX74recA1endA1araD1 } \\
\quad 39 \triangle \text { (araleu) 7697galUga/KrpsLnupG } \lambda_{-}\end{array}$ & Thermo Fisher Scientific \\
\hline $\mathrm{DH} 10 \mathrm{~B} \triangle \mathrm{g} \ln A$ & $\mathrm{DH} 10 \mathrm{~B} \Delta g \ln A::$ FRT-kan ${ }^{R}-\mathrm{FRT}$ & This study \\
\hline $\mathrm{DH} 10 \mathrm{~B} \triangle \mathrm{gdhA}$ & DH10B $\triangle g d h A::$ FRT-kan ${ }^{R}-\mathrm{FRT}$ & This study \\
\hline \multicolumn{3}{|l|}{ Plasmids } \\
\hline pTrcHis2-TOPO & $P_{\text {trc }}:$ TOPO site, $\mathrm{pBR} 322$ ori, $/ \operatorname{lac}^{9}, \mathrm{Amp}^{R}$ & Thermo Fisher Scientific \\
\hline $\begin{array}{l}\text { Control plasmid (pTrcHis2- } \\
\text { lacZ) }\end{array}$ & $P_{\text {trc }}:$ lacZ, pBR322 ori, lacl $^{q}, A m p^{R}$ & Thermo Fisher Scientific \\
\hline pTrcHis2-kivd & $P_{\text {trc }}:$ kivd, pBR322 ori, lacl $^{q}, A m p^{R}$ & This study, Accession number: AJ746364.1 \\
\hline pTrcHis2-cadA & $P_{\text {trc }}:$ cadA, pBR322 ori, 1 acl $1^{9}, A m p^{R}$ & This study, Accession number: AY319765.1 \\
\hline pTrcHis2-gadA & $P_{\text {trc: }}$ gadA, pBR322 ori, lacl $^{9}, A m p^{R}$ & This study, Accession number: EF547388.1 \\
\hline pTrcHis2-ilvH & $P_{\text {trc }}:$ ilvH, pBR322 ori, $\mid a l^{9}, A m p^{R}$ & This study, Accession number: EG10499 \\
\hline pKD46 & Red recombinase expression plasmid & Datsenko et al. (2000) \\
\hline pKD13 & $K a n^{R}$ template plasmid & Datsenko et al. (2000) \\
\hline
\end{tabular}




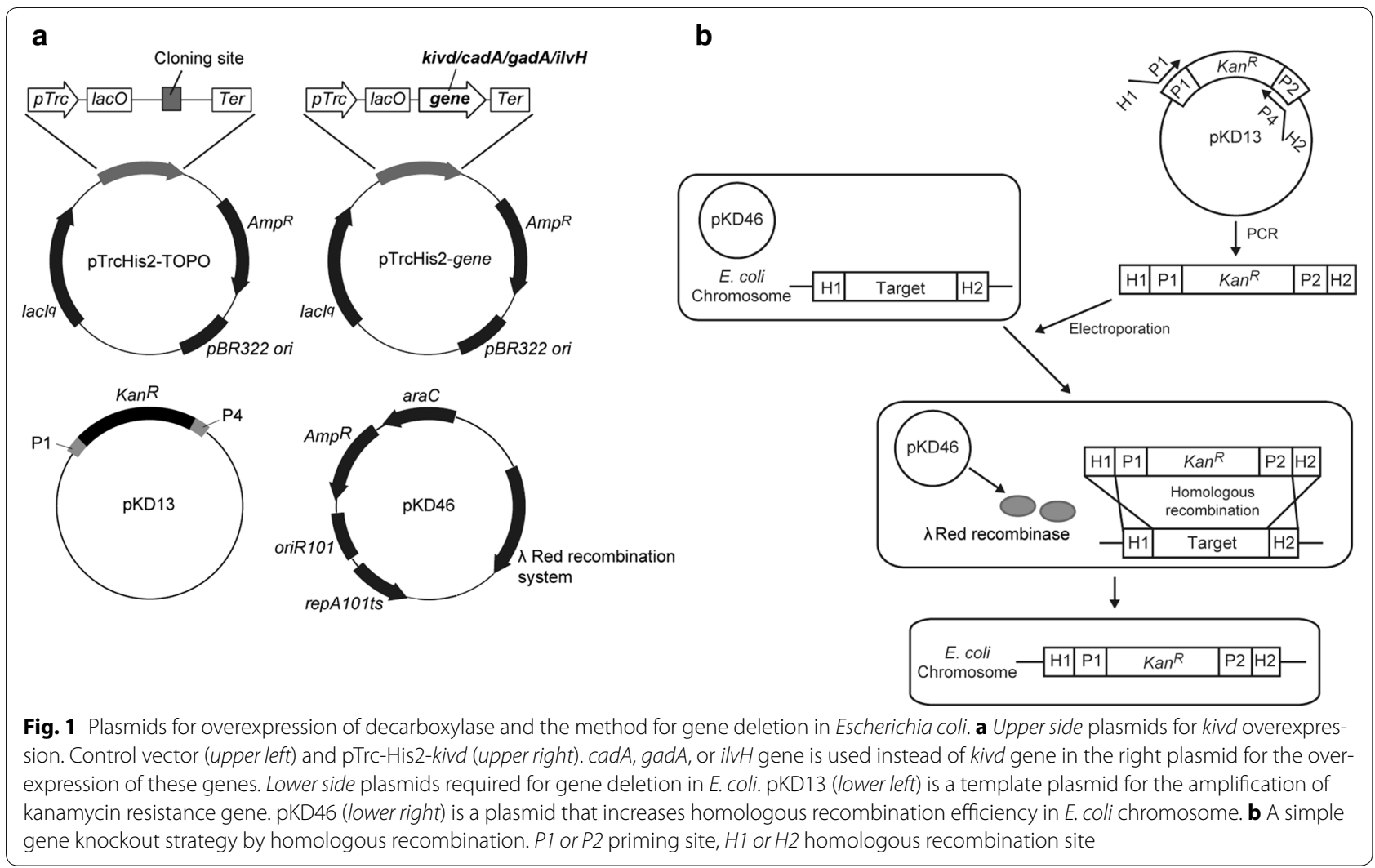

nitrogen-containing media were calculated based on the nitrogen contents in the BD Bionutrients ${ }^{\mathrm{TM}}$ Technical Manual Third edition (BD Biosciences 2015). Referring to the manual, for example, the theoretical maximum ammonia production in M9-YE medium (containing $7.25 \mathrm{~g} / \mathrm{L}$ of yeast extract) was calculated to be $960 \mathrm{mg} / \mathrm{L}$.

\section{Results}

\section{Overexpression of 2-keto acid decarboxylase genes}

To produce ammonia from amino acids, we planned to modify catabolism of amino acids in E. coli. The catabolic pathway of amino acids in E. coli is shown in Fig. 2. Natively, ammonia lyases such as $i l v A$ (Eisenstein 1990), or transaminases such as $i l v E$ (Inoue et al. 1988) catalyze the elimination of amino groups from amino acids. As a result of the elimination of amino groups, 2-keto acids are produced. Thus, we hypothesized that an irreversible decarboxylation of these 2-keto acids could be a driving force to engineer the metabolic flux toward ammonia production (Fig. 3, upper).

First, we examined the effect of selected decarboxylases on ammonia production; kivd ( $\alpha$-ketoisovalerate decarboxylase) (de la Plaza et al. 2004), gadA (glutamate decarboxylase) (Waterman and Small 2003), cadA (lysine decarboxylase) (Lemonnier and Lane 1998), and $i l v H$ (acetolactate synthase) (Defelice et al. 1974). In these experiments, ammonia production was performed in M9-YE medium using yeast extract as the sole source of carbon and nitrogen. We used yeast extract as a model of waste biomass because it contains abundant amino acids as a nitrogen source (Biosciences 2015). As a result, we found that the kivd-overexpressing $E$. coli strain achieved the highest ammonia production $(351 \mathrm{mg} / \mathrm{L}, 36.6 \%$ yield $)$, while the control $E$. coli strain produced some ammonia using the native ammonia metabolism (Table 2).

Gene deletion of $E$. coli to improve ammonia production To improve the efficacy of ammonia production, we deleted genes involved in ammonia assimilation. We chose two genes, $g \ln A$ (glutamine synthetase) and $g d h A$ (glutamate dehydrogenase), as knockout candidates to produce increased amounts of ammonia (Fig. 3, lower). Glutamate and glutamine are the major products of ammonia assimilation and they serve as intracellular nitrogen donors. Glutamine synthetase (GS) and glutamate dehydrogenase $(\mathrm{GDH})$ assimilate most of the ammonia in E. coli, according to following reactions (van Heeswijk et al. 2013):

$$
\begin{aligned}
& \mathrm{GDH}(g d h A): \alpha \text {-Ketoglutarate }+\mathrm{NH}_{3}+\mathrm{NADPH} \\
& \rightarrow \text { Glutamate }+\mathrm{NADP}^{+}
\end{aligned}
$$




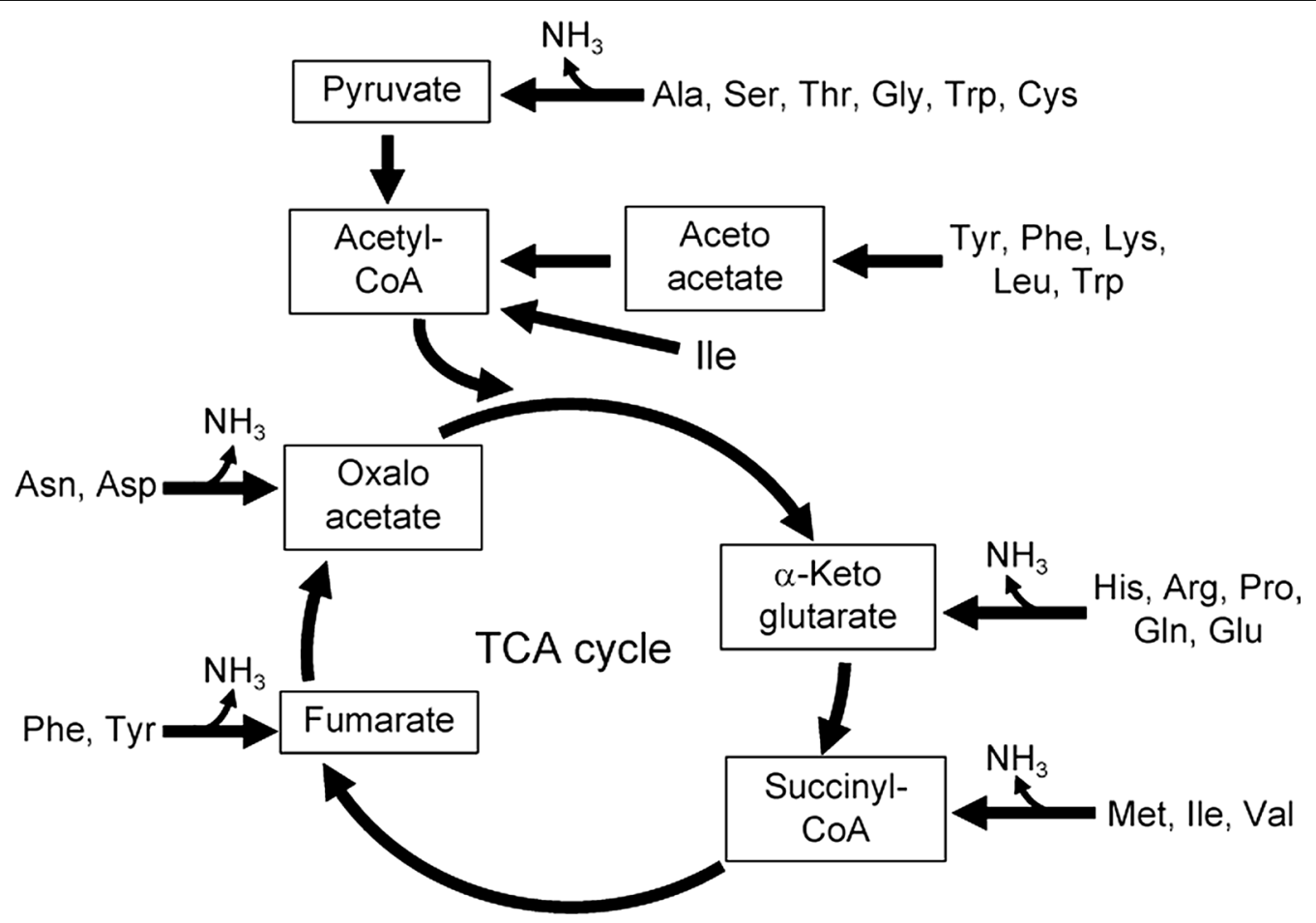

Fig. 2 Catabolic pathway of amino acids

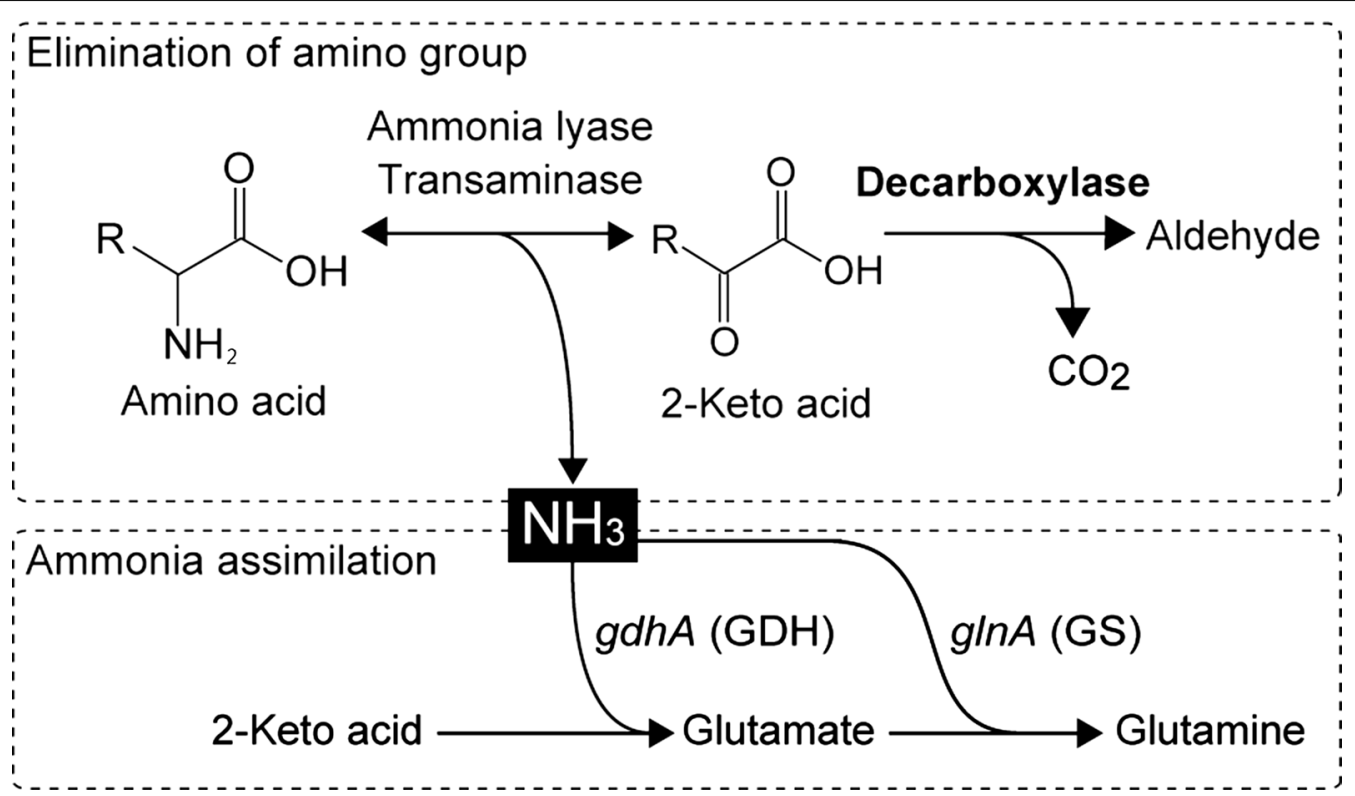

Fig. 3 Scheme of ammonia production. Elimination process of amino groups (upper). Assimilation process of amino groups (lower)

$$
\begin{aligned}
& \text { GS }(g \ln A): \text { Glutamate }+\mathrm{NH}_{3}+\mathrm{ATP} \\
& \quad \rightarrow \text { Glutamine }+\mathrm{ADP}+\mathrm{Pi}
\end{aligned}
$$

Deletion of $g \ln A(\triangle g \ln A)$ or $g d h A$ blocks ammonia reuptake and lead to secretion of ammonia into the media.
Therefore, we individually deleted each of these genes in $E$. coli to try to improve ammonia yield. The amount of ammonia produced by these gene-deleted strains was evaluated in combination with the overexpression of kivd in M9-YE medium. As shown in Fig. 4, ammonia 
Table 2 Growth and ammonia production of decarboxylase-overexpressing E. coli strains in M9_YE medium

\begin{tabular}{|c|c|c|c|c|}
\hline Sample & Cell density $\mathrm{OD}_{600}$ & $\begin{array}{l}\text { Produced ammonia } \\
\text { by } E . \text { coli (mg/L) }\end{array}$ & $\begin{array}{l}\text { Theoretical amount of maximum } \\
\text { ammonia production }(\mathrm{mg} / \mathrm{L})^{\mathrm{a}}\end{array}$ & Yield (\%) \\
\hline Medium only & $0.0253 \pm 0.0073$ & $24.2 \pm 2.7$ & 960 & 2.50 \\
\hline Control strain & $3.73 \pm 0.05$ & $260 \pm 11$ & 960 & 27.1 \\
\hline kivd & $2.31 \pm 0.09$ & $351 \pm 5$ & 960 & 36.6 \\
\hline cadA & $5.11 \pm 0.03$ & $230 \pm 6$ & 960 & 24.0 \\
\hline $\operatorname{gad} A$ & $2.89 \pm 0.01$ & $256 \pm 6$ & 960 & 26.7 \\
\hline ilvH & $5.61 \pm 0.07$ & $239 \pm 26$ & 960 & 24.9 \\
\hline
\end{tabular}

Values of yield were calculated as produced ammonia by E. coli per theoretical amount of maximum ammonia production. Values given as mean \pm SD ( $\mathrm{n}=3$ )

a The values were calculated based on the nitrogen contents of BD Bionutrients ${ }^{\mathrm{TM}}$ Technical Manual Third edition (http://www.bd.com/ds/technicalCenter/misc/ Icn01558-bionutrients-manual.pdf.)

production reached $458 \mathrm{mg} / \mathrm{L}$ ( $47.8 \%$ yield) when the overexpression of kivd and deletion of $g \ln A$ was combined. The reason why ammonia production did not improve in the $g d h A$ deleted strain (Fig. 4) was thought to be a property of GDH. GDH has low affinity for ammonia $\left(\mathrm{K}_{\mathrm{M}}=1-2 \mathrm{mM}\right)$ (Sharkey and Engel 2008), while GS has high affinity $\left(K_{M}=0.1 \mathrm{mM}\right)$ (van Heeswijk et al. 2013). Hence, GDH is less efficient in low ammonia concentrations, such as in M9-YE medium.

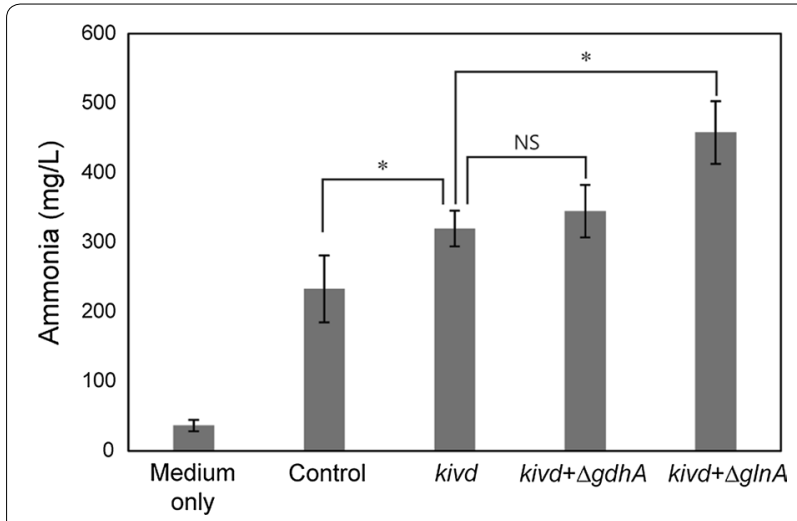

Fig. 4 Ammonia production of modified strains. Values given as mean $\pm S D(n \geq 3)$. *Statistical significances are determined by Tukey test $(P<0.01)$. NS no significance
Next, we examined the effect of nitrogen source on ammonia production. Efficiency of ammonia production is affected by nitrogen content and difficulty of decomposition. Four media were used for ammonia production by the kivd $+\Delta g \ln A$ strain (Table 3). The yield in M9-YE medium was higher than that in the other media, except for the medium using casamino acids. The yields from peptone or tryptone media were low, probably because they contain long-chain peptides that $E$. coli cannot degrade (Huo et al. 2011). The ammonia yield from casamino acids was slightly higher than that from yeast extract (Table 3 ). The reason may be that the content of amino nitrogen per total nitrogen in casamino acids is higher than that in yeast extract (Table 4), leading to efficient ammonia production in casamino acid-based medium by $E$. coli.

\section{Discussion}

The demand for ammonia is expected to grow in the future. Recent studies examined ammonia production using microorganisms such as nitrogen-fixing bacteria (Higo et al. 2016). In this study, we focused on waste biomass, which has abundant nitrogen-containing compounds. By engineering ammonia metabolism in E. coli, the best strain produced $458 \mathrm{mg} / \mathrm{L}$ of ammonia from $7.25 \mathrm{~g} / \mathrm{L}$ of yeast extract (Fig. 4). This ammonia yield is $23 \%$ higher than that in the previous study (Choi et al. 2014). Our study demonstrated that ammonia could be

Table 3 Ammonia production by the kivd $+\Delta g \ln A$ strain with various nitrogen sources (7.25 g/L)

\begin{tabular}{|c|c|c|c|c|}
\hline Nitrogen source & Cell density $\mathrm{OD}_{600}$ & $\begin{array}{l}\text { Produced ammonia } \\
\text { by } E \text {. coli (mg/L) }\end{array}$ & $\begin{array}{l}\text { Theoretical amount of maximum } \\
\text { ammonia production }(\mathrm{mg} / \mathrm{L})^{\mathrm{a}}\end{array}$ & Yield (\%) \\
\hline Yeast extract (M9_YE) & $1.51 \pm 0.05$ & $439 \pm 12$ & 960 & 45.8 \\
\hline Tryptone & $1.25 \pm 0.08$ & $427 \pm 25$ & 1171 & 36.5 \\
\hline Peptone & $1.00 \pm 0.06$ & $375 \pm 10$ & 1356 & 27.7 \\
\hline Casamino acids & $0.99 \pm 0.03$ & $453 \pm 35$ & 951 & 47.6 \\
\hline
\end{tabular}

Values of yield were calculated as produced ammonia by $E$. coli per theoretical amount of maximum ammonia production. Values given as mean $\pm S D(n=3)$

a The values were calculated based on the nitrogen contents of BD Bionutrients ${ }^{\mathrm{TM}}$ Technical Manual Third edition (http://www.bd.com/ds/technicalCenter/misc/ Icn01558-bionutrients-manual.pdf.) 
Table 4 Compositions of various nitrogen-containing sources

\begin{tabular}{|c|c|c|c|c|c|c|}
\hline Nitrogen source & $\begin{array}{l}\text { Total nitrogen } \\
{[\mathrm{TN}, \%(\mathrm{w} / \mathrm{w})]}\end{array}$ & $\begin{array}{l}\text { Amino nitrogen } \\
{[A N, \%(w / w)]}\end{array}$ & AN/TN (\%) & $\begin{array}{l}\text { Total amino acids } \\
{[\%(w / w)]}\end{array}$ & $\begin{array}{l}\text { Free amino acids } \\
{[\%(w / w)]}\end{array}$ & $\begin{array}{l}\text { Free amino acids/ } \\
\text { total amino acids (\%) }\end{array}$ \\
\hline Yeast extract & 10.9 & 6.0 & 55.0 & 52.2 & 32.8 & 62.8 \\
\hline Tryptone & 13.3 & 5.3 & 39.8 & 76.4 & 26.9 & 35.2 \\
\hline Peptone & 15.4 & 3.5 & 22.7 & 72.4 & 14.8 & 20.4 \\
\hline Casamino acids & 10.8 & 9.4 & 87.0 & 62.8 & 51.0 & 81.2 \\
\hline
\end{tabular}

The values were calculated based on the nitrogen contents of BD Bionutrients ${ }^{\mathrm{TM}}$ Technical Manual Third edition (http://www.bd.com/ds/technicalCenter/misc/ Icn01558-bionutrients-manual.pdf). Total amino acids include forms of protein and peptide

recovered in a low energy-consuming manner and that it would be possible to cover some of the increasing demand for ammonia in the future.

As shown in Table 4, yeast extract (Becton) was selected as the nitrogen source because more than $60 \%$ of nitrogen-containing compounds in yeast extract are easily degradable amino acids. The yield of ammonia is affected by the form of nitrogen in a medium. As shown in Table 3, the ammonia yield in M9-YE medium was higher than the media using peptone or tryptone, and equivalent to the medium using casamino acids. While yeast extract or casamino acids contain a lot of amino acids, peptone and tryptone consist of proteins and longchain peptides (Table 4). Because E. coli cannot directly utilize proteins and long-chain peptides as a nutrient source, they must be decomposed into short-chain peptides before ammonia production (Huo et al. 2011). This is done by heterologous expression of strong proteases in E. coli (Choi et al. 2014; Su et al. 2012).

The ammonia yield with the best strain $(k i v d+\Delta g \ln A)$ reached $47.8 \%$. The remaining $52.2 \%$ was thought to be used for cell biomass or not catabolized. In order to increase the yield of ammonia, it is necessary to balance the growth of $E$. coli and ammonia production. The more $E$. coli grows, the less ammonia is produced in media, because overgrowth of $E$. coli leads to accumulation of ammonia in the form of cell biomass. Optimization of the balance between growth and ammonia production will be required to achieve the best yield. There have been studies trying to produce chemicals efficiently with the minimum growth required for production (Soma et al. 2014; Brockman and Prather 2015). For example, Soma et al. constructed two modes, a growth mode and a production mode, and engineered cells transitioned from growth mode to production mode automatically in culture. Strategies taken in these studies can be applied to increase ammonia yield.

\section{Additional file}

Additional file 1: Table S1. Primers

\section{Abbreviations}

E. coli: Escherichia coli; SDS-PAGE: sodium dodecyl sulfate-polyacrylamide gel electrophoresis; IPTG: isopropyl- $\beta$-D-thiogalactoside; GS: glutamine synthetase; GDH: glutamate dehydrogenase; $B$. subtilis: Bacillus subtilis.

\section{Authors' contributions}

Planning and designing of study: YM, HY, YT, WA, MU; Experimentation and result analysis: YM, HY; Manuscript Drafting: YM, HY, YT, WA, MU. All authors read and approved the final manuscript.

\section{Author details}

1 Division of Applied Life Sciences, Graduate School of Agriculture, Kyoto University, Sakyo-ku, Kyoto 606-8502, Japan. ${ }^{2}$ Japan Society for Promotion of Science, Sakyo-ku, Kyoto 606-8502, Japan. ${ }^{3}$ Kyoto Industrial Science and Technology Innovation Center, Shimogyo-ku, Kyoto 600-8813, Japan.

\section{Acknowledgements}

We are grateful to Prof. Taizo Hanai (Kyushu University) for the kind gift of plasmids and advice for gene deletion.

\section{Competing interests}

The authors declare that they have no competing interests.

\section{Availability of data and materials}

All the data are presented in the main paper or Additional file 1.

\section{Consent for publication}

This article does not contain any individual person's data.

\section{Ethical approval}

This article does not contain any studies concerned with experimentation on human or animals.

\section{Publisher's Note}

Springer Nature remains neutral with regard to jurisdictional claims in published maps and institutional affiliations.

Received: 2 March 2017 Accepted: 7 April 2017

Published online: 20 April 2017

\section{References}

BD biosciences (2015) BD bionutrients ${ }^{\mathrm{TM}}$ Technical Manual. Available via DIALOG. http://www.bd.com/ds/technicalCenter/misc/lcn01558-bionutrients-manual.pdf. Accessed 10 Feb 2017

Brockman IM, Prather KLJ (2015) Dynamic knockdown of E. coli central metabolism for redirecting fluxes of primary metabolites. Metab Eng 28:104-113

Choi KY, Wernick DG, Tat CA, Liao JC (2014) Consolidated conversion of protein waste into biofuels and ammonia using Bacillus subtilis. Metab Eng 23:53-61

Datsenko KA, Wanner BL (2000) One-step inactivation of chromosomal genes in Escherichia coli K-12 using PCR products. Proc Natl Acad Sci USA 97:6640-6645 
de la Plaza M, de Palencia PF, Pelaez C, Requena T (2004) Biochemical and molecular characterization of alpha-ketoisovalerate decarboxylase, an enzyme involved in the formation of aldehydes from amino acids by Lactococcus lactis. FEMS Microbiol Lett 238:367-374

Defelice M, Guardiola J, Esposito B, laccarino M (1974) Structural genes for a newly recognized acetolactate synthase in Escherichia-coli K-12. J Bacteriol 120:1068-1077

Deng MD, Severson DK, Grund AD, Wassink SL, Burlingame RP, Berry A, Running JA, Kunesh CA, Song L, Jerrell TA, Rosson RA (2005) Metabolic engineering of Escherichia coli for industrial production of glucosamine and $\mathrm{N}$-acetylglucosamine. Metab Eng 7:201-214

Eisenstein E (1990) Cloning, expression, purification, and characterization of biosynthetic threonine deaminase from Escherichia coli. J Biol Chem 266:5801-5807

Erisman JW, Sutton MA, Galloway J, Klimont Z, Winiwarter W (2008) How a century of ammonia synthesis changed the world. Nat Geosci 1:636-639

Gocha A (2015) USGS mineral commodity summary 2015 highlights. Am Ceram Soc Bull 94:33-35

Higo A, Isu A, Fukaya Y, Hisabori T (2016) Efficient gene induction and endogenous gene repression systems for the filamentous Cyanobacterium Anabaena sp. PCC 7120. Plant Cell Physiol 57:387-396

Huo YX, Cho KM, Rivera JGL, Monte E, Shen CR, Yan YJ, Liao JC (2011) Conversion of proteins into biofuels by engineering nitrogen flux. Nat Biotechnol 29:346-351

Inoue K, Kuramitsu S, Aki K, Watanabe Y, Takagi T, Nishigai M, Ikai A, Kagamiyama H (1988) Branched-chain amino acid aminotransferase of Escherichia coli: overproduction and properties. J Biol Chem 104:777-784

Lan R, Irvine JTS, Tao SW (2012) Ammonia and related chemicals as potential indirect hydrogen storage materials. Int J Hydrogen Energy 37:1482-1494
Lemonnier M, Lane D (1998) Expression of the second lysine decarboxylase gene of Escherichia coli. Microbiol Sgm 144:751-760

Miura D, Tezuka T (2014) A comparative study of ammonia energy systems as a future energy carrier, with particular reference to vehicle use in Japan. Energy 68:428-436

Schrock RR (2006) Reduction of dinitrogen. Proc Natl Acad Sci USA 103:17087 Sharkey MA, Engel PC (2008) Apparent negative co-operativity and substrate inhibition in overexpressed glutamate dehydrogenase from Escherichia coli. FEMS Microbiol Lett 281:132-139

Soma Y, Tsuruno K, Wada M, Yokota A, Hanai T (2014) Metabolic flux redirection from a central metabolic pathway toward a synthetic pathway using a metabolic toggle switch. Metab Eng 23:175-184

Su LQ, Chen S, Yi L, Woodard RW, Chen J, Wu J (2012) Extracellular overexpression of recombinant Thermobifida fusca cutinase by alpha-hemolysin secretion system in E. coli BL21(DE3). Microb Cell Fact 11:8

van Heeswijk WC, Westerhoff HV, Boogerd FC (2013) Nitrogen assimilation in Escherichia coli: putting molecular data into a systems perspective. Microbiol Mol Biol Rev 77:628-695

Waterman SR, Small PLC (2003) Transcriptional expression of Escherichia coli glutamate-dependent acid resistance genes gadA and gadBC in an hns rpoS mutant. J Bacteriol 185:4644-4647

Yim H, Haselbeck R, Niu W, Pujol-Baxley C, Burgard A, Boldt J, Khandurina J, Trawick JD, Osterhout RE, Stephen R, Estadilla J, Teisan S, Schreyer HB, Andrae S, Yang TH, Lee SY, Burk MJ, Van Dien S (2011) Metabolic engineering of Escherichia coli for direct production of 1,4-butanediol. Nat Chem Biol 7:445-452

\section{Submit your manuscript to a SpringerOpen ${ }^{\odot}$ journal and benefit from:}

- Convenient online submission

- Rigorous peer review

- Immediate publication on acceptance

- Open access: articles freely available online

- High visibility within the field

- Retaining the copyright to your article

Submit your next manuscript at springeropen.com 